\title{
A COMPARISON OF SEVERAL EXTRACTION PROCEDURES FOR RABBIT ACROSOMAL ENZYMES
}

\author{
R. STAMBAUGH AND M. SMITH \\ Division of Reproductive Biology, Department of Obstetrics and Gynecology, \\ University of Pennsylvania School of Medicine, Philadelphia, \\ Pennsylvania 19174, U.S.A.
}

\section{(Received 9th February 1973)}

A variety of enzymes, lipids and polysaccharides have been described as 'acrosomal' and implicated in the fertilization process (Hathaway \& Hartree, 1963; Srivastava, Adams \& Hartree, 1965; Hartree \& Srivastava, 1965; Stambaugh \& Buckley, 1968, 1969; Allison \& Hartree, 1970; Zaneveld, Srivastava \& Williams, 1969; Zaneveld, Polakoski \& Williams, 1972). Several extraction procedures have been used specifically for removing the acrosomal contents, and it seemed appropriate to compare and reinvestigate their specificity. It was hoped that this comparison might provide some insight into the specificity of each procedure, and the need for additional criteria to label an extract or enzyme as 'acrosomal'.

The first method examined involved a direct extraction of washed spermatozoa with detergents. By this procedure, epididymal spermatozoa were washed three times with isotonic saline, and the washed spermatozoa were extracted with $0 \cdot 15 \%$ Hyamine containing $0.15 \%$ Triton X. 100 . A number of variations of this procedure are in use at the present time (Hartree \& Srivastava, 1965; Srivastava et al., 1965; Zaneveld et al., 1969; Ho \& Meizel, 1970; Garner, Salisbury \& Graves, 1971; Polakoski, Zaneveld \& Williams, 1972).

In the second method, the spermatozoa were pre-washed three times with a

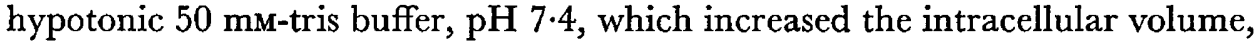
causing the plasma membrane to stretch and allowing proteins to escape. The washed spermatozoa were then extracted with $0.1 \%$ Hyamine in $0.067 \mathrm{M}$-trismaleate buffer, $\mathrm{pH} 6 \cdot 1$.

The third method involved a subcellular fractionation of the spermatozoa before extraction of the acrosomal enzymes. Rabbit epididymal spermatozoa were disrupted by mild sonication and fractionated subcellularly into heads, mid-pieces, tails and soluble enzymes by the procedure of Stambaugh \& Buckley $(1968,1969,1970)$ on sucrose density gradients. The isolated heads were then extracted with $0.1 \%$ Hyamine in $0.067 \mathrm{~m}$-tris-maleate buffer, $\mathrm{pH}$ $6 \cdot 1$, and the extract was centrifuged and dialysed against isotonic $\mathrm{NaCl}$.

Protein concentrations in these experiments were determined by the method of Lowry, Rosebrough, Farr \& Randall (1951). Acrosomal proteinase activity on benzoyl-L-arginine ethyl ester was measured spectrophotometrically by the procedure of Bergmeyer (1963) and confirmed using $\mathcal{N}$-benzoyl-DL-arginine $p$-nitroanilide BAPNA by the procedure of Erlanger, Kowsky \& Cohen (1961). 
Chymotrypsin-like activity on benzoyl-L-tyrosine ethyl ester was measured spectrophotometrically by the procedure of Hummel (1959). Hyaluronidase was measured by the turbidimetric method of Tolksdorf, McCready, McCullogh \& Sichwenk (1949). Catalase activity was measured spectrophotometrically by the method of Beers \& Sizer (1952). Acid phosphatase was measured by the rate of hydrolysis of 0 -carboxyphenylphosphate by the procedure of Brandenberger \& Hanson (1953). Total lactic dehydrogenase was determined by the procedure of Stambaugh \& Post (1966). Leucine aminopeptidase was measured by the procedure of Mitz \& Schlueter (1958). Aldolase was determined by the procedure of Blostein \& Rutter (1963). Malic dehydrogenase was assayed by the procedure of Siegel \& Bing (1956), and carboxypeptidase was determined by the method of Folk \& Schirmer (1963).

Table 1. Comparison of three procedures for extracting rabbit sperm acrosomal enzymes

\begin{tabular}{|c|c|c|c|c|c|c|}
\hline \multirow[b]{2}{*}{ Acrosomal proteinase } & \multicolumn{2}{|c|}{$\begin{array}{l}\text { (1) Direct detergent } \\
\text { extraction }\end{array}$} & \multicolumn{2}{|c|}{$\begin{array}{l}\text { (2) Prewashing with } \\
\text { hypotonic buffer }\end{array}$} & \multirow{2}{*}{\multicolumn{2}{|c|}{$\begin{array}{l}\begin{array}{l}\text { (3) Subcellular } \\
\text { fractionation }\end{array} \\
2 \cdot 23 \mathrm{U} / \mathrm{mg} \text { protein }\end{array}$}} \\
\hline & 1.96 & $\mathrm{U} / \mathrm{mg}$ protein & $4 \cdot 87$ & $7 \mathrm{U} / \mathrm{mg}$ protein & & \\
\hline Hyaluronidase & $65 \cdot 0$ & $\mathrm{U} / \mathrm{mg}$ protein & 549 & $\mathrm{U} / \mathrm{mg}$ protein & $69 \cdot 5$ & $\mathrm{U} / \mathrm{mg}$ protein \\
\hline Malic dehydrogenase & $62 \cdot 3 x$ & $\mathrm{mU} / \mathrm{mg}$ protein & 337 & $\mathrm{mU} / \mathrm{mg}$ protein & & 0 \\
\hline$\alpha$-Chymotrypsin & 95.0 & $\mathrm{mU} / \mathrm{mg}$ protein & $57 \cdot 7$ & $\mathrm{mU} / \mathrm{mg}$ protein & & 0 \\
\hline Aldolase & 147 & $\mathrm{mU} / \mathrm{mg}$ protein & $2 \cdot 77$ & $\mathrm{mU} / \mathrm{mg}$ protein & & 0 \\
\hline Leucine aminopeptidase & $8 \cdot 21$ & $\mathrm{U} / \mathrm{mg}$ protein & $25 \cdot 9$ & $\mathrm{U} / \mathrm{mg}$ protein & & 0 \\
\hline Garboxypeptidase & & 0 & & 0 & & 0 \\
\hline $\begin{array}{l}\text { Lactic dehydrogenase } \\
\quad(\mathbf{M}+\mathbf{H} \text { kinetic types })\end{array}$ & 304 & $\mathrm{mU} / \mathrm{mg}$ protein & 266 & $\mathrm{mU} / \mathrm{mg}$ protein & & 0 \\
\hline Acid phosphatase & & trace & & trace & & trace \\
\hline Catalase & 724 & $\mathrm{mU} / \mathrm{mg}$ protein & & 0 & & 0 \\
\hline
\end{tabular}

Using Method 1, a wide spectrum of enzymes was obtained (Table 1), but many of them appeared to be unrelated to the biological function of the acrosome and its contents. Good extractions of acrosomal proteinase and hyaluronidase were obtained by this procedure, but aldolase and lactic dehydrogenase, which function in anaerobic glycolysis, were also extracted with high specific activities. In addition, malic dehydrogenase, a mitochondrial enzyme, was present in high concentrations. Other enzymes present in these extracts were catalase, traces of acid phosphatase, and two proteolytic enzymes: a chymotrypsin-like enzyme, and an aminopeptidase.

By Method 2, many of the contaminating enzymes were removed completely or reduced in concentration (Table 1). Catalase was completely removed by the pretreatment with hypotonic buffer, while aldolase, lactic dehydrogenase, acid phosphatase, and the chymotrypsin-like enzyme were reduced in concentration. Malic dehydrogenase, however, was present in considerably higher specific activities than in extracts prepared by the other two procedures. Acrosomal proteinase and hyaluronidase were also extracted in excellent yields.

Method 3 reduced the number of enzymes detectable in the acrosomal 
extracts. Of the enzymes assayed, only acrosomal proteinase, hyaluronidase and a trace of acid phosphatase were present.

The results from Method 1 would seem to indicate that a direct detergent extraction of washed rabbit epididymal spermatozoa extracts a number of enzymes which are unlikely to be acrosomal in origin. The most noteworthy of these are malic dehydrogenase, aldolase and lactic dehydrogenase, enzymes involved in the anaerobic pathway of glycolysis. Neither optical nor electron microscopy possess the resolution to reveal whether the permeability of the membrane to macromolecules has been altered by the extraction reagent.

A procedure involving a prewash of the spermatozoa with hypotonic buffer before the acrosomal enzyme extraction was initiated by Allison \& Hartree (1970). Although malic dehydrogenase, aldolase and lactic dehydrogenase are still present in the extracts, the prewash improves the specificity of the procedure and does, in some way, increase the susceptibility of hyaluronidase and acrosomal proteinase to extraction by detergents. Quantitatively, this would seem to be the most desirable procedure to use.

Only hyaluronidase, acrosomal proteinase, and a trace of acid phosphatase were found in the Method-3 extracts. Teichman \& Bernstein (1969) demonstrated that this acid phosphatase was localized in the sub-equatorial and postacrosomal region of the head, and it seems reasonable that the enzyme might originate by adsorption onto the outer acrosomal membrane in view of its close proximity in the spermatozoon. It is possible that some acrosomal enzymes may have been lost during the subcellular fractionation.

This study indicates that the types of enzymes extracted depend on the procedure employed, and cytochemistry or other appropriate procedures should be applied, whenever possible, to give additional evidence for the subcellular localization of acrosomal enzymes (Allison \& Hartree, 1970; Yanagimachi \& Teichman, 1972; Stambaugh \& Buckley, 1972).

This work was supported by NIH Contract No. 70-2161, Ford Foundation Grant 650-0058B, and Program Project Grant NIH-1-PO1-HD-6274-01.

\section{REFERENCES}

Allison, A. G. \& Hartree, E. F. (1970) Lysosomal enzymes in the acrosome and their possible rôle in fertilization. F. Reprod. Fert. 21, 501.

BEERs, R. T., JR \& SizER, J. W. (1952) A spectrophotometric method for measuring the breakdown of hydrogen peroxide by catalase. 7. biol. Chem. 195, 133.

Bergmeyer, H. U. (1963) Methods of enzymatic analysis, p. 815. Academic Press, New York.

Blostein, R. \& Rutrer, W. J. (1963) Comparative studies of liver and muscle aldolase. F. biol. Chem. 238, 3280 .

Brandenserger, H. \& Hanson, R. (1953) Spectrophotometric determination of acid and alkaline phosphatases. Helv. chim. Acta, 36, 900.

ErLanger, B. F., Kowsky, N. \& Cohen, W. (1961) The preparation and properties of two new chromogenic substrates of trypsin. Archs Biochem. Biophys. 95, 271.

Folk, J. E. \& Schirmer, E. Q. (1963) The porcine pancreatic carboxypeptidase A system. F. biol. Chem. 238, 3884 .

Garner, D. L., Salisbury, G. W. \& Graves, C. N. (1971) Electrophoretic fractionation of bovine acrosomal proteins and proteinase. Biol. Reprod. 4, 93.

Hartree, E. T. \& Srivastava, P. N. (1965) Chemical composition of the acrosomes of ram spermatozoa. 7. Reprod. Fert. 9, 47. 
HathaWAy, R. R. \& HaRTREe, E. T. (1963) Observations on the mammalian acrosomes from ram and bull spermatozoa. F. Reprod. Fert. 5, 225.

Ho, J. J. L. \& MeIzes, S. (1970) Electrophoretic detection of multiple forms of trypsin-like activity in spermatozoa of the domestic fowl. F. Reprod. Fert. 23, 177.

HuMmell, B. C. W. (1959) A modified spectrophotometric determination of chymotrypsin, trypsin, and thrombin. Can. F. Biochem. Physiol. 37, 1393.

Lowry, O. H., Rosebrough, N. J., FarR, A. L. \& Randall, R. J. (1951) Protein measurement with the Folin phenol reagent. F. biol. Chem. 193, 265.

Mrtz, M. A. \& Schlueter, R. J. (1958) Direct spectrophotometric measurement of the peptide bond: application to the determination of acylase 1. Biochim. biophys. Acta, 27, 168.

Polakoski, K. L., Zaneveld, L. J. D. \& Williams, W. L. (1972) Purification of a proteolytic enzyme from rabbit acrosomes. Biol. Reprod. 6, 23.

Stegel, A. \& Bing, R. J. (1956) Plasma enzyme activity in myocardial infarction in dog and man. Proc. Soc. exp. Biol. Med. 91, 604.

Srivastava, P. N., Adams, C. E. \& Hartree, E. F. (1965) Enzymic action of acrosomal preparations on the rabbit ovum in vitro. F. Reprod. Fert. 10,61.

Stambaugh, R. \& Buckley, J. (1968) Zona pellucida dissolution enzymes of the rabbit sperm head. Science, $\mathcal{N}$. $. .161,585$.

Stambaugh, R. \& Buckley, J. (1969) Identification and subcellular localization of the enzymes effecting penetration of the zona pellucida by rabbit spermatozoa. F. Reprod. Fert. 19, 423.

Stambaugh, R. \& Buckley, J. (1970) Comparative studies of the acrosomal enzymes of rabbit, rhesus monkey, and human spermatozoa. Biol. Reprod. 3, 275.

Stambaugh, R. \& Buckley, J. (1972) Histochemical subcellular localization of the acrosomal proteinase effecting dissolution of the zona pellucida using fluorescein-labeled inhibitors. Fert. Steril. 23, 348.

Stambaugh, R. \& Post, D. (1966) A spectrophotometric method for the assay of lactic dehydrogenase subunits. Analyt. Biochem. 15, 470.

Teichman, R. J. \& Bernstein, M. H. (1969) A morphological and biochemical comparison of rabbit, human and bull acrosomes. F. Cell Biol. 43, 144a.

Tolksdorf, S., McCready, M. H., McCullogh, D. R. \& Sichwenk, E. (1949) The turbidimetric assay of hyaluronidase. F. Lab. clin. Med. 34, 74.

Yanagimachi, R. \& Teichman, R. J. (1972) Cytochemical demonstration of acrosomal proteinase in mammalian and avian spermatozoa by a silver proteinate method. Biol. Reprod. 6, 87.

Zaneveld, L. J. D., Polakoski, K. L. \& Williams, W. L. (1972) Properties of a proteolytic enzyme from rabbit sperm acrosomes. Biol. Reprod. 6, 30.

Zaneveld, L. J. D., Srivastava, P. N. \& Williams, W. L. (1969) Relationship of a trypsin-like enzyme in rabbit spermatozoa to capacitation. F. Reprod. Fert. 20, 337. 